\title{
Progressive Myoclonus Epilepsies
}

\section{Diagnostic Yield With Next-Generation Sequencing in Previously Unsolved Cases}

\author{
Laura Canafoglia, MD, PhD, Silvana Franceschetti, MD, PhD, Antonio Gambardella, MD, Pasquale Striano, MD, \\ Anna Teresa Giallonardo, MD, Paolo Tinuper, MD, Carlo Di Bonaventura, MD, Roberto Michelucci, MD, \\ Edoardo Ferlazzo, MD, Tiziana Granata, MD, Adriana Magaudda, MD, Laura Licchetta, MD, \\ Alessandro Filla, MD, Angela La Neve, MD, Patrizia Riguzzi, MD, Teresa Anna Cantisani, MD, \\ Martina Fanella, MD, PhD, BARBARA CASTELLOTTI, PhD, Cinzia Gellera, PhD, Melanie Bahlo, PhD, \\ Federico Zara, PhD, Carolina Courage, PhD, Anna-Elina Lehesjoki, PhD, Karen L. Oliver, PhD, and \\ Samuel F. Berkovic, MD
}

Neurol Genet 2021;7:e641. doi:10.1212/NXG.0000000000000641

\section{Abstract}

\section{Background and Objectives}

To assess the current diagnostic yield of genetic testing for the progressive myoclonus epilepsies (PMEs) of an Italian series described in 2014 where Unverricht-Lundborg and Lafora diseases accounted for $\sim 50 \%$ of the cohort.

\section{Methods}

Of 47/165 unrelated patients with PME of indeterminate genetic origin, 38 underwent new molecular evaluations. Various next-generation sequencing (NGS) techniques were applied including gene panel analysis $(\mathrm{n}=7)$ and/or whole-exome sequencing (WES) (WES singleton $\mathrm{n}=29$, WES trio $\mathrm{n}=7$, and WES sibling $\mathrm{n}=4$ ). In 1 family, homozygosity mapping was followed by targeted NGS. Clinically, the patients were grouped in 4 phenotypic categories: "Unverricht-Lundborg disease-like PME," "late-onset PME," "PME plus developmental delay," and "PME plus dementia."

\section{Results}

Sixteen of 38 (42\%) unrelated patients reached a positive diagnosis, increasing the overall proportion of solved families in the total series from $72 \%$ to $82 \%$. Likely pathogenic variants were identified in NEU1 (2 families), CERS1 ( 1 family), and in 13 nonfamilial patients in KCNC1 (3), DHDDS (3), SACS, CACNA2D2, STUB1, AFG3L2, CLN6, NAXE, and CHD2. Across the different phenotypic categories, the diagnostic rate was similar, and the same gene could be found in different phenotypic categories.

\section{Discussion}

The application of NGS technology to unsolved patients with PME has revealed a collection of very rare genetic causes. Pathogenic variants were detected in both established PME genes and

\author{
Correspondence \\ Dr. Franceschetti \\ silvana.franceschetti@ \\ istituto-besta.it
}

\begin{abstract}
From the Neurophysiopathology (L.C., S.F.), Fondazione IRCCS Istituto Neurologico Carlo Besta, Milan; Department of Medical and Surgical Sciences (A.G., E.F.), Magna Graecia University, Catanzaro; IRCCS Istituto "G. Gaslini" (P.S., F.Z.), Genova; Department of Neurosciences (P.S., F.Z.), Rehabilitation, Ophthalmology, Genetics, Maternal and Child Health, University of Genoa, Genova; Department of Human Neurosciences (T.G., C.D.B., M.F.), Sapienza University of Rome, Viale dell'Università, Rome; IRCCS Istituto delle Scienze Neurologiche di Bologna (P.T., L.L.), Epilepsy Center, Bologna; Department of Biomedical and Neuromotor Sciences (P.T., L.L.), University of Bologna; IRCCS Istituto delle Scienze Neurologiche di Bologna (R.M., P.R.), Unit of Neurology, Bellaria Hospital, Bologna; Regional Epilepsy Centre (E.F.), BMM Great Metropolitan Hospital, Via Melacrino, Reggio Calabria; Department of Pediatric Neuroscience (T.G.), Fondazione IRCCS Istituto Neurologico Carlo Besta, Milan; Epilepsy Center (A.M.), Department of Clinical and Experimental Medicine, AOU Policlinico "G. Martino", Messina; Department of Neuroscience (A.F.), Reproductive, and Odontostomatological Sciences, University of Naples Federico II, Naples; Department of Basic Medical Sciences (A.L.N.), Neuroscience and Sense Organs, University of Bari “Aldo Moro”, Piazza Giulio Cesare 11, Bari ; Perugia Hospital (T.A.C,), Neurophysiopathology Unit, Azienda Ospedaliera di Perugia, S. Andrea delle Fratte, Perugia; Unit of Genetics of Neurodegenerative and Metabolic Diseases (B.C., C.G.), IRCCS Istituto Neurologico Carlo Besta, Milan, Italy; Population Health and Immunity Division (M.B., K.L.O.), The Walter and Eliza Hall Institute of Medical Research, Parkville; Department of Medical Biology (M.B., K.L.O.), The University of Melbourne; Folkhälsan Research Center (C.C., A.E.L.); Department of Medical and Clinical Genetics, Medicum, University of Helsinki, Finland; and Epilepsy Research Centre (K.L.O., S.F.B), Department of Medicine, University of Melbourne, Austin Health, Heidelberg, Victoria, Australia.
\end{abstract}




\section{Glossary}

NGS = next-generation sequencing; PME = progressive myoclonus epilepsy; ULD = Unverricht-Lundborg disease; WES = whole-exome sequencing.

in genes not previously associated with PME, but with progressive ataxia or with developmental encephalopathies. With a diagnostic yield $>80 \%$, PME is one of the best genetically defined epilepsy syndromes.

Progressive myoclonus epilepsies (PMEs) are caused by heterogeneous genetic disorders and present with cortical myoclonus, generalized tonic-clonic seizures, and variable ataxia or cognitive impairment. In a multicenter Italian collaborative study, we reported the etiologies in a cohort of 204 PME patients from 165 unrelated families studied by classical pathologic, biochemical, and targeted genetic testing. ${ }^{1}$ The cohort included "classical" PMEs, such as Unverricht-Lundborg (progressive myoclonic epilepsy type 1 [EPM1], 33\%) and Lafora body (EPM2, 20\%) diseases, and other PMEs resulting from more rare genetic diseases (19\%). In 47 unrelated patients (28\%), the etiology remained unidentified (Figure 1).

Since 2014, novel genetic causes and pathogenetic mechanisms for PME have been identified. These include pathogenic variants in CERS $1,{ }^{2}$ involved in ceramide metabolism, $\mathrm{KCNCl}{ }^{3}{ }^{3}$ with a dominant-negative effect on the voltage-gated $\mathrm{K}_{\mathrm{V}} 3$ channel, ${ }^{4}$ and the NUS1, DHDDS, and ALG10 genes, involved in dolichol-dependent protein glycosylation. ${ }^{5}$

We reanalyze the unsolved cases in the 2014 series $^{1}$ to assess the impact of newer diagnostic procedures, especially next-generation sequencing (NGS). Most of the newly solved cases have been reported elsewhere ${ }^{2-6}$; we herein provide an overall perspective of the current diagnostic yield in PME.

\section{Methods}

We studied 38 unsolved unrelated PME patients who did not reach a positive causal diagnosis in our previously reported PME series; DNA was no longer available from the remaining 9 patients (Figure 2). We obtained informed consent from all patients (or their guardians), in line with local institutional review board requirements for genetic analyses. Seven unrelated patients were initially investigated using a NGS panel containing 240 genes known to cause epilepsies or PME. Subsequently, 29 unrelated patients including 3 unsolved by the panel had singleton whole-exome sequencing (WES). ${ }^{3}$ A trio-design WES approach was performed in 7 patients, including 2 unsolved by NGS panel and 5 unsolved by singleton WES. In 4 families with 2 or 3 affected siblings, WES was performed on all patients. ${ }^{5}$ In 1 family with 4 affected siblings, homozygosity mapping was followed by targeted NGS. ${ }^{2}$

All patients presented with cortical myoclonus and a progressive course, consistent with PME. The clinical presentation of each patient was reviewed by Istituto Neurologico Besta clinicians (L.C. and S.F.) and researchers at the University of Melbourne (K.L.O. and S.F.B.). Taking into account the clinical classification applied by Courage et al., ${ }^{5}$ patients were categorized as (1) "Unverricht-Lundborg disease-like (ULD-like) PME” in case of late childhood/

Figure 1 Classification of 165 Families With PME From 2014 to 2021
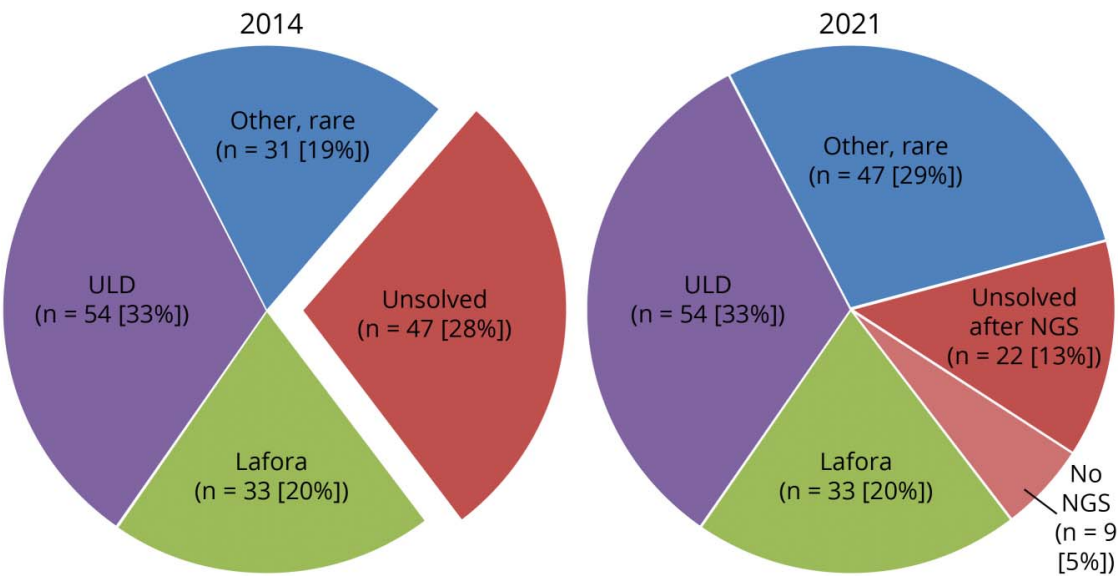

NGS = next-generation sequencing; PME = progressive myoclonus epilepsy; ULD = UnverrichtLundborg disease. 


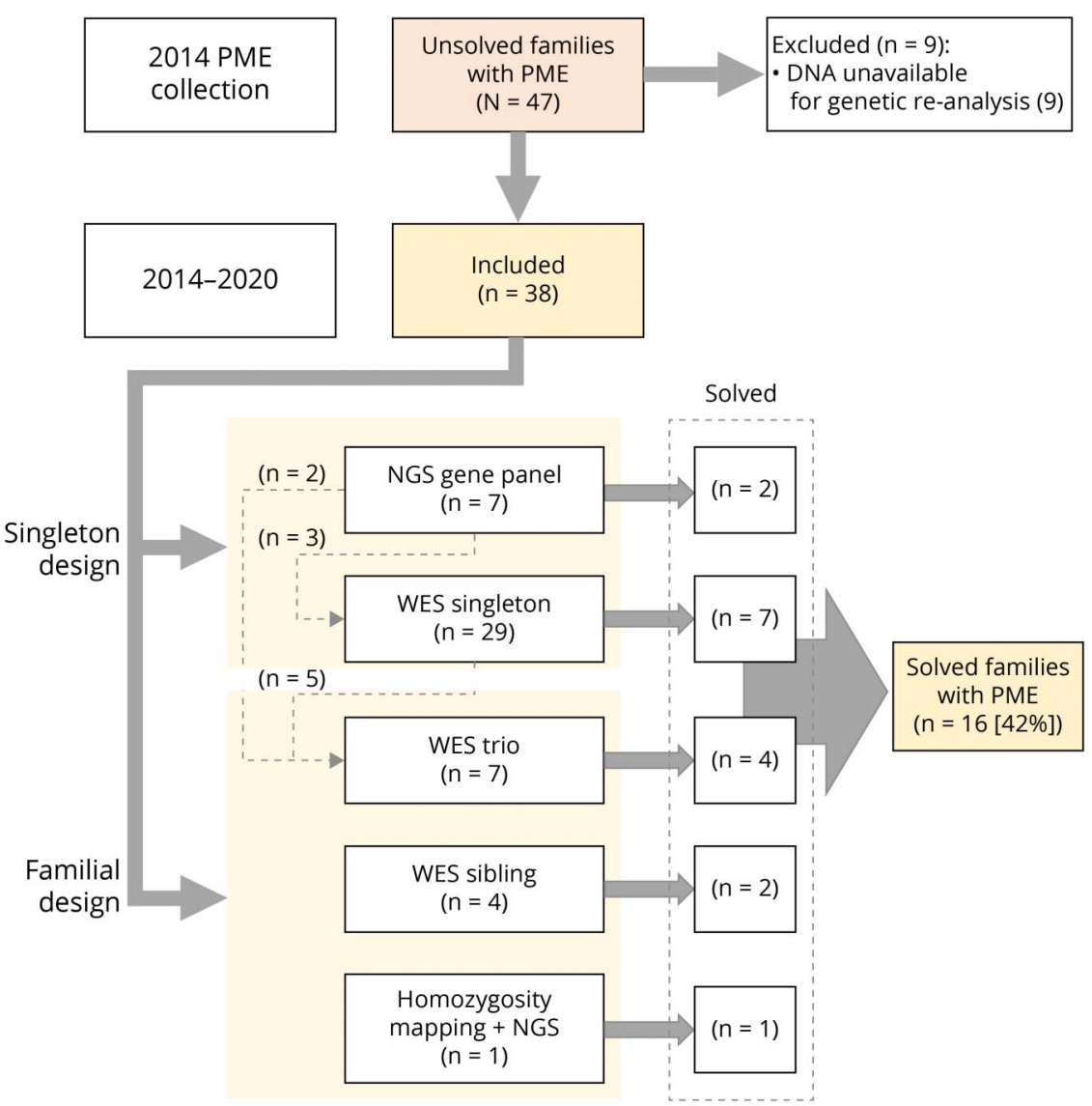

NGS = next-generation sequencing; $\mathrm{PME}=$ progressive myoclonus epilepsy; WES = wholeexome sequencing. adolescent onset of cortical myoclonus and minimal cognitive impairment similar to EPM1, (2) "late-onset PME" in case of clinical presentation similar to EPM1, but onset after 20 years of age, (3) "PME plus developmental delay" when progressive cortical myoclonus appeared after other symptoms suggesting a developmental encephalopathy (early psychomotor delay, ataxia or seizures), and (4) "PME plus dementia" when patients showed a severe and progressive cognitive impairment as part of the phenotype.

\section{Data Availability}

Anonymized data can be made available to qualified investigators upon request to the corresponding author.

\section{Results}

We found genetic causes in 16 of the 38 unrelated patients (42\%). As shown in Figure 2, 2 patients were solved by NGS panel, 7 by WES singleton, 4 by WES trio, 2 by WES sibling, and 1 by homozygosity mapping. ${ }^{2-6}$ Table 1 reports the newly identified genetic variants.

Among "ULD-like" (16 cases), 3 had pathogenic variants in KCNC1 and 3 in CHD2, DHDDS, or AFG3L2. The genetic defect remained undetermined in the remaining 10. Among
"late-PME" (6 patients), the WES of siblings revealed different NEU1 pathogenic variants in 2 families, mutation of DHDDS in 1 patient, and mutation of CLN6 in 1 other. In 2, the genetic cause remained unidentified.

In "PME plus developmental delay," we included 11 patients. Homozygosity mapping revealed a pathogenic missense variant in CERS1 (EPM8; \#616230) in 4 siblings, belonging to an Algerian family. ${ }^{2}$ Four sporadic cases had pathogenic variants in NAXE, DHDDS, SACS, and $C A C N A 2 D 2$. In the remaining 6 patients, the genetic cause remained unidentified.

Among the 5 patients with "PME plus dementia," 1 had a pathogenic variant in STUB1.

In the 2014 article, ${ }^{1}$ a cluster analysis based on clinical features associated with PME allowed grouping the 38 unsolved patients evenly into Cluster $1(n=20)$ and Cluster $2(n=18)$. Cluster 1 accounted for all patients now classified as "PME plus developmental delay" with a smaller subset of "ULD-like" and "PME plus dementia" patients. Cluster 2 was predominantly made up of "ULD-like" patients, all "late-onset PME" patients, and 1 patient classified as "PME plus dementia" (eFigure 1, links.lww.com/NXG/A490). Diagnostic 
Table 1 Pathogenic Variants Detected in 16/38 Unsolved PME Families Since 2014

\begin{tabular}{|c|c|c|c|c|c|c|}
\hline Gene & $\mathbf{N}$ & Variant(s) & Inheritance & Study & Citation & Phenotype \\
\hline KCNC1 & 1 & c.959 G > A; p.Arg320His (Het) & de novo & WES singleton & $\begin{array}{l}\text { Muona et al., } \\
2015^{3}\end{array}$ & "ULD-like" (Cluster 1) \\
\hline KCNC1 & 1 & c.959 G > A; p.Arg320His (Het) & de novo & WES singleton & $\begin{array}{l}\text { Muona et al., } \\
2015^{3}\end{array}$ & “ULD-like" (Cluster 1) \\
\hline KCNC1 & 1 & c.959 G > A; p.Arg320His (Het) & de novo & NGS panel & Oliver et al., $2017^{4}$ & "ULD-like" (Cluster 2) \\
\hline AFG3L2 & 1 & c.1875 G > A; p.Met625Ile (Hom) & $A R$ & WES singleton & $\begin{array}{l}\text { Muona et al., } \\
2015^{3}\end{array}$ & “ULD-like” (Cluster 2) \\
\hline DHDDS & 1 & c.614 G > A; p.Arg205Gln (Het) & - & WES singleton & $\begin{array}{l}\text { Courage et al., } \\
2021^{5}\end{array}$ & “ULD-like” (Cluster 2) \\
\hline CHD2 & 1 & c.1541_1567del; p.(514_523del) (Het) & - & WES singleton & - & “ULD-like” (Cluster 1) \\
\hline NEU1 & $3 \mathrm{sib}$ & c.200 G > T; p.Ser67lle (Hom) & $A R$ & WES sibling (quartet) & $\begin{array}{l}\text { Canafoglia et al., } \\
2014^{6}\end{array}$ & "Late PME" (Cluster 2) \\
\hline NEU1 & $2 \mathrm{sib}$ & $\begin{array}{l}\text { c.679 G > A; p.Gly227Arg; c.913C > T; p.Arg305Cys } \\
\text { (Comp Het) }\end{array}$ & AR & WES sibling (pair) & $\begin{array}{l}\text { Canafoglia et al., } \\
2014^{6}\end{array}$ & "Late PME" (Cluster 2) \\
\hline CLN6 & 1 & $\begin{array}{l}\text { c.814C > G; p. Leu272Val; c.721A> G; p.Met241Val } \\
\text { (Comp Het) }\end{array}$ & AR & NGS panel & $\begin{array}{l}\text { Berkovic et al., } \\
2019^{8}\end{array}$ & "Late PME" (Cluster 2) \\
\hline DHDDS & 1 & c.283 G > A; p.Asp95Asn (Het) & - & WES singleton & $\begin{array}{l}\text { Courage et al., } \\
2021^{5}\end{array}$ & "Late PME" (Cluster 2) \\
\hline CERS1 & $4 \mathrm{sib}$ & c.549C > G; p.His183Gln (Hom) & $A R$ & $\begin{array}{l}\text { Homozygosity mapping } \\
+ \text { NGS }\end{array}$ & Vanni et al., $2014^{2}$ & "PME + DD" (Cluster 1) \\
\hline NAXE & 1 & c. $128 \mathrm{C}>$ A; p.Ser43Ter (Hom) & $\mathrm{AR}$ & WES trio & $\begin{array}{l}\text { Courage et al., } \\
2021^{5}\end{array}$ & "PME + DD" (Cluster 1) \\
\hline DHDDS & 1 & c.632 G > A; p.Arg211Gln (Het) & de novo & WES trio & $\begin{array}{l}\text { Courage et al., } \\
2021^{5}\end{array}$ & “PME + DD" (Cluster 1) \\
\hline SACS & 1 & $\begin{array}{l}\text { c.8393C > A, p.Pro2798GIn c.2996T > C; } \\
\text { p.lle999Thr (Comp Het) }\end{array}$ & $\mathrm{AR}$ & WES singleton & $\begin{array}{l}\text { Muona et al., } \\
2015^{3}\end{array}$ & "PME + DD" (Cluster 1) \\
\hline CACNA2D2 & 1 & $\begin{array}{l}\text { c. } 1260 \text { G > A; p.Thr420 = c. } 1112 A>\text { G, p.Tyr371Cys } \\
\text { (Comp Het) }\end{array}$ & AR & WES trio & $\begin{array}{l}\text { Courage et al., } \\
2021^{5}\end{array}$ & "PME + DD" (Cluster 1) \\
\hline STUB1 & 1 & c.169C > T, p; Pro57Ser (Hom) & $\mathrm{AR}$ & WES trio & $\begin{array}{l}\text { Courage et al., } \\
2021^{5}\end{array}$ & $\begin{array}{l}\text { "PME + Dementia” } \\
\text { (Cluster 1) }\end{array}$ \\
\hline
\end{tabular}

Abbreviations: Comp Het = compound heterozygote; Het = heterozygous; Hom = homozygous; Late PME = late-onset PME; NGS = next-generation sequencing; PME + DD = PME plus developmental delay; ULD-like = Unverricht-Lundborg disease-like.

success was achieved in 9/20 Cluster 1 cases and $7 / 18$ for Cluster 2.

Overall, concerning the 165 PME unrelated patients reported in 2014, the genetically identified causes increased from $72 \%$ to $82 \%$. Figure 1 compares the diagnostic yield and breakdown for the entire Italian series from 2014 to 2021 and (eTable 1, links.lww.com/NXG/A490) lists all genes with pathogenic variants.

\section{Discussion}

This reanalysis with next-generation sequencing resulted in a positive diagnosis in $42 \%$ of PME unrelated patients who were unsolved at the time of our previous study. ${ }^{1}$ One clinically relevant observation relates to the atypical presentation of known PME disorders, which can hinder the diagnosis, as occurred with the diagnosis of sialidosis $(\# 256550)$ in 2 families. Patients presented as "late-onset PME" and escaped diagnosis because of nonindicative biochemical findings and an unapparent cherry-red spot. ${ }^{6}$

Since 2014, NGS facilitated the discovery of many pathogenic variants in genes not previously identified as a causative for PME. ${ }^{5}$ Some, such as $\mathrm{KCNC} 1,{ }^{3,4}$ can be considered "specific" PME genes, giving rise in a typical age-range to a classical picture of worsening cortical myoclonus. Other findings, however, suggest that in some patients, in whom the syndromic picture is still that of a PME, the disorder results as a "variant" phenotype of genetic disorders typically presenting with other symptoms. In fact, until the studies published by Muona et al., ${ }^{3}$ and Courage et al., ${ }^{5}$ AFG3L2 (\#614487), SACS (\#270550), and STUB1 (\#615768) were known to be associated with autosomal recessive ataxia and CACNA2D2 (\#618501) with ataxia or epileptic encephalopathy. The spectrum 
of NAXE is phenotypically broad, giving rise to lethal neurometabolic disorder with acute-onset ataxia or epilepsy and movement disorders, occasionally including myoclonus. ${ }^{7} \mathrm{CHD} 2$ is a well-established epileptic encephalopathy gene and was only recently associated with PME. ${ }^{5}$

The "new" genetic diagnoses were similarly distributed between "Cluster 1 and 2" that we identified in our original 2014 report, ${ }^{1}$ and the same occurred for the 4 phenotypic categories applied in this study. Moreover, mutations of the same gene, for instance DHDDS, may result either in "PME plus developmental delay," "ULD-like PME," or "late-onset PME" phenotypes. Conversely, we did not observe different phenotype categories within families.

Previous retrospective series from referral centers have reported high diagnostic yields in PME, ${ }^{8-10}$ but these studies likely suffer from referral and recall biases. Although the Italian series is not strictly epidemiologic, it was multicenter and had a prospective component, so it approximates the realworld representation of PME in a Caucasian population without major founder effects.

A methodological limit of this study resides on heterogeneous diagnostic procedures preceding WES. Our observation may indicate that, following an early screening of the most classical causes of PME (e.g., EPM1, resulting from CSTB dodecamer repeat expansion), and in the absence of typical signs revealing well-known disorders causing PME (e.g., cherry-red spot in sialidoses), WES represents the most suitable diagnostic procedure for achieving the causal diagnosis in the unsolved patients. When possible, affected family members and unaffected parents should be sequenced to maximize diagnostic yield and the chances for novel discovery.

The extensive re-evaluation by means of WES in our unclassified cases suggests that in PME it is possible to achieve a high genetic diagnostic yield $(>80 \%)$, thus making PMEs 1 of the most genetically well-defined groups of all epilepsies.

\section{Acknowledgment}

The authors would like to thank the Italian League Against Epilepsy (LICE), which helped to support this study and continues to support many other epilepsy research studies.

\section{Study Funding}

No targeted funding reported.

\section{Disclosure}

The authors have no disclosure to make in relation to this manuscript. Go to Neurology.org/NG for full disclosure.

\section{Publication History}

Received by Neurology: Genetics August 20, 2021. Accepted in final form October 8, 2021.
Appendix Authors

\begin{tabular}{lll}
\hline Name & Location & Contribution \\
\hline $\begin{array}{ll}\text { Laura } \\
\text { Manafoglia, }\end{array}$ & $\begin{array}{l}\text { Neurophysiopathology, } \\
\text { Fondazione IRCCS Istituto }\end{array}$ & $\begin{array}{l}\text { Drafting/revision of the } \\
\text { manuscript for content, } \\
\text { including medical writing } \\
\text { for content, major role in } \\
\text { the acquisition of data, } \\
\text { Milan, Italy }\end{array}$ \\
& $\begin{array}{l}\text { study concept or design, } \\
\text { and analysis or } \\
\text { interpretation of data }\end{array}$ \\
\end{tabular}

\begin{tabular}{|c|c|c|}
\hline $\begin{array}{l}\text { Silvana } \\
\text { Franceschetti, } \\
\text { MD, PhD }\end{array}$ & $\begin{array}{l}\text { Neurophysiopathology, } \\
\text { Fondazione IRCCS Istituto } \\
\text { Neurologico Carlo Besta, } \\
\text { Milan, Italy }\end{array}$ & $\begin{array}{l}\text { Drafting/revision of the } \\
\text { manuscript for content, } \\
\text { including medical writing } \\
\text { for content, major role in } \\
\text { the acquisition of data, } \\
\text { study concept or design, } \\
\text { and analysis or } \\
\text { interpretation of data }\end{array}$ \\
\hline
\end{tabular}

\begin{tabular}{lll}
\hline $\begin{array}{l}\text { Antonio } \\
\text { Gambardella, } \\
\text { MD }\end{array}$ & $\begin{array}{l}\text { Department of Medical and } \\
\text { Surgical Sciences, Magna } \\
\text { Graecia University, } \\
\text { Catanzaro, Italy }\end{array}$ & $\begin{array}{l}\text { Drafting/revision of the } \\
\text { manuscript for content, } \\
\text { including medical writing } \\
\text { for content, and major role } \\
\text { in the acquisition of data }\end{array}$ \\
\hline $\begin{array}{l}\text { Pasquale } \\
\text { Striano, MD }\end{array}$ & $\begin{array}{l}\text { IRCCS Istituto "G. Gaslini," } \\
\text { Genova, Italy; Department of } \\
\text { Neurosciences, Rehabilitation, } \\
\text { Ophthalmology, Genetics, } \\
\text { Maternal and Child Health, } \\
\text { University of Genoa, Genova, } \\
\text { Italy }\end{array}$ & $\begin{array}{l}\text { Drafting/revision of the } \\
\text { incling medical writing } \\
\text { for content, and major role } \\
\text { in the acquisition of data }\end{array}$ \\
& $\begin{array}{l}\text { Department of Human } \\
\text { Neurosciences, Sapienza }\end{array}$ & $\begin{array}{l}\text { Drafting/revision of the } \\
\text { manuscript for content, } \\
\text { including medical writing } \\
\text { Giallonardo, } \\
\text { MD }\end{array}$ \\
\hline $\begin{array}{l}\text { University of Rome, Viale } \\
\text { dell'Università, Italy }\end{array}$ & $\begin{array}{l}\text { for content, and major role } \\
\text { in the acquisition of data }\end{array}$ \\
\hline
\end{tabular}

Paolo Tinuper, IRCCS Istituto delle Scienze Drafting/revision of the MD Neurologiche di Bologna, manuscript for content Epilepsy Center; including medical writing Department of Biomedical for content, and major role and Neuromotor Sciences, in the acquisition of data University of Bologna, Italy

\begin{tabular}{lll}
\hline Carlo Di & Department of Human & Drafting/revision of the \\
Bonaventura, & Neurosciences, Sapienza \\
MD & $\begin{array}{l}\text { University of Rome, Viale } \\
\text { dell'Università, Italy }\end{array}$ & $\begin{array}{l}\text { including medical writing } \\
\text { for content, and major role } \\
\text { in the acquisition of data }\end{array}$ \\
\end{tabular}

Roberto IRCCS Istituto delle Scienze Drafting/revision of the Michelucci, Neurologiche di Bologna, manuscript for content, MD Unit of Neurology, Bellaria including medical writing Hospital, Bologna, Italy for content, and major role in the acquisition of data

\begin{tabular}{lll}
\hline $\begin{array}{l}\text { Edoardo } \\
\text { Ferlazzo, MD }\end{array}$ & $\begin{array}{l}\text { Department of Medical and } \\
\text { Surgical Sciences, Magna } \\
\text { Graecia University, Catanzaro, } \\
\text { Italy; Regional Epilepsy Centre, } \\
\text { BMM Great Metropolitan } \\
\text { Hospital, Via Melacrino, } \\
\text { Reggio Calabria, Italy }\end{array}$ & $\begin{array}{l}\text { Drafting/revision of the } \\
\text { manuscript for content, } \\
\text { for content, and major role } \\
\text { in the acquisition of data }\end{array}$ \\
\hline $\begin{array}{l}\text { Tiziana } \\
\text { Granata, MD }\end{array}$ & $\begin{array}{l}\text { Department of Pediatric } \\
\text { Neuroscience, Fondazione }\end{array}$ & $\begin{array}{l}\text { Drafting/revision of the } \\
\text { manuscript for content, } \\
\text { IRCCS Istituto Neurologico } \\
\text { including medical writing } \\
\text { for content, and major role }\end{array}$ \\
& $\begin{array}{l}\text { Carlo Besta, Milan, Italy } \\
\text { in the acquisition of data }\end{array}$ \\
\hline $\begin{array}{l}\text { Adriana } \\
\text { Magaudda, } \\
\text { MD }\end{array}$ & $\begin{array}{l}\text { Epilepsy Center, } \\
\text { Department of Clinical and } \\
\text { Experimental Medicine, }\end{array}$ & $\begin{array}{l}\text { Drafting/revision of the } \\
\text { manuscript for content, } \\
\text { including medical writing } \\
\text { for content, and major role } \\
\text { in the acquisition of data }\end{array}$ \\
& $\begin{array}{l}\text { AOU Policlinico "G. } \\
\text { Martino," Messina, Italy }\end{array}$ &
\end{tabular}


Appendix (continued)

\begin{tabular}{|c|c|c|}
\hline Name & Location & Contribution \\
\hline $\begin{array}{l}\text { Laura } \\
\text { Licchetta, MD }\end{array}$ & $\begin{array}{l}\text { IRCCS Istituto delle Scienze } \\
\text { Neurologiche di Bologna, } \\
\text { Epilepsy Center, Italy; } \\
\text { Department of Biomedical } \\
\text { and Neuromotor Sciences, } \\
\text { University of Bologna, Italy }\end{array}$ & $\begin{array}{l}\text { Drafting/revision of the } \\
\text { manuscript for content, } \\
\text { including medical writing } \\
\text { for content, and major role } \\
\text { in the acquisition of data }\end{array}$ \\
\hline $\begin{array}{l}\text { Alessandro } \\
\text { Filla, MD }\end{array}$ & $\begin{array}{l}\text { Department of } \\
\text { Neuroscience, } \\
\text { Reproductive, and } \\
\text { Odontostomatological } \\
\text { Sciences, University of } \\
\text { Naples Federico II, Italy }\end{array}$ & $\begin{array}{l}\text { Drafting/revision of the } \\
\text { manuscript for content, } \\
\text { including medical writing } \\
\text { for content, and major role } \\
\text { in the acquisition of data }\end{array}$ \\
\hline $\begin{array}{l}\text { Angela La } \\
\text { Neve, MD }\end{array}$ & $\begin{array}{l}\text { Department of Basic } \\
\text { Medical Sciences, } \\
\text { Neuroscience and Sense } \\
\text { Organs, University of Bari } \\
\text { "Aldo Moro," Piazza Giulio } \\
\text { Cesare 11, Italy }\end{array}$ & $\begin{array}{l}\text { Drafting/revision of the } \\
\text { manuscript for content, } \\
\text { including medical writing } \\
\text { for content, and major role } \\
\text { in the acquisition of data }\end{array}$ \\
\hline $\begin{array}{l}\text { Patrizia } \\
\text { Riguzzi, MD }\end{array}$ & $\begin{array}{l}\text { IRCCS Istituto delle Scienze } \\
\text { Neurologiche di Bologna, } \\
\text { Unit of Neurology, Bellaria } \\
\text { Hospital, Italy }\end{array}$ & $\begin{array}{l}\text { Drafting/revision of the } \\
\text { manuscript for content, } \\
\text { including medical writing } \\
\text { for content, and major role } \\
\text { in the acquisition of data }\end{array}$ \\
\hline $\begin{array}{l}\text { Teresa Anna } \\
\text { Cantisani, MD }\end{array}$ & $\begin{array}{l}\text { Perugia Hospital, } \\
\text { Neurophysiopathology } \\
\text { Unit, Azienda Ospedaliera } \\
\text { di Perugia, S. Andrea delle } \\
\text { Fratte, Italy }\end{array}$ & $\begin{array}{l}\text { Drafting/revision of the } \\
\text { manuscript for content, } \\
\text { including medical writing } \\
\text { for content, and major role } \\
\text { in the acquisition of data }\end{array}$ \\
\hline $\begin{array}{l}\text { Martina } \\
\text { Fanella, MD, } \\
\text { PhD }\end{array}$ & $\begin{array}{l}\text { Department of Human } \\
\text { Neurosciences, Sapienza } \\
\text { University of Rome, Viale } \\
\text { dell'Università, Italy }\end{array}$ & $\begin{array}{l}\text { Drafting/revision of the } \\
\text { manuscript for content, } \\
\text { including medical writing } \\
\text { for content, and major role } \\
\text { in the acquisition of data }\end{array}$ \\
\hline $\begin{array}{l}\text { Barbara } \\
\text { Castellotti, } \\
\text { PhD }\end{array}$ & $\begin{array}{l}\text { Unit of Genetics of } \\
\text { Neurodegenerative and } \\
\text { Metabolic Diseases, IRCCS } \\
\text { Istituto Neurologico Carlo } \\
\text { Besta, Milan, Italy }\end{array}$ & $\begin{array}{l}\text { Drafting/revision of the } \\
\text { manuscript for content, } \\
\text { including medical writing } \\
\text { for content, and major role } \\
\text { in the acquisition of data }\end{array}$ \\
\hline $\begin{array}{l}\text { Cinzia Gellera, } \\
\text { PhD }\end{array}$ & $\begin{array}{l}\text { Unit of Genetics of } \\
\text { Neurodegenerative and } \\
\text { Metabolic Diseases, IRCCS } \\
\text { Istituto Neurologico Carlo } \\
\text { Besta, Milan, Italy }\end{array}$ & $\begin{array}{l}\text { Drafting/revision of the } \\
\text { manuscript for content, } \\
\text { including medical writing } \\
\text { for content, and major role } \\
\text { in the acquisition of data }\end{array}$ \\
\hline $\begin{array}{l}\text { Melanie Bahlo, } \\
\text { PhD }\end{array}$ & $\begin{array}{l}\text { Population Health and } \\
\text { Immunity Division, The } \\
\text { Walter and Eliza Hall } \\
\text { Institute of Medical } \\
\text { Research, Parkville; } \\
\text { Department of Medical } \\
\text { Biology, The University of } \\
\text { Melbourne, VIC, Australia }\end{array}$ & $\begin{array}{l}\text { Drafting/revision of the } \\
\text { manuscript for content, } \\
\text { including medical writing } \\
\text { for content, and major role } \\
\text { in the acquisition of data }\end{array}$ \\
\hline $\begin{array}{l}\text { Federico Zara, } \\
\text { PhD }\end{array}$ & $\begin{array}{l}\text { IRCCS Istituto "G. Gaslini," } \\
\text { Genova, Italy; Department of } \\
\text { Neurosciences, Rehabilitation, } \\
\text { Ophthalmology, Genetics, } \\
\text { Maternal and Child Health, } \\
\text { University of Genoa, Genova, } \\
\text { Italy }\end{array}$ & $\begin{array}{l}\text { Drafting/revision of the } \\
\text { manuscript for content, } \\
\text { including medical writing } \\
\text { for content, and major role } \\
\text { in the acquisition of data }\end{array}$ \\
\hline
\end{tabular}

Appendix (continued)

\begin{tabular}{|c|c|c|}
\hline Name & Location & Contribution \\
\hline $\begin{array}{l}\text { Carolina } \\
\text { Courage, PhD }\end{array}$ & $\begin{array}{l}\text { Folkhälsan Research } \\
\text { Center, Helsinki, Finland; } \\
\text { Department of Medical and } \\
\text { Clinical Genetics, Medicum, } \\
\text { University of Helsinki, } \\
\text { Finland }\end{array}$ & $\begin{array}{l}\text { Drafting/revision of the } \\
\text { manuscript for content, } \\
\text { including medical writing } \\
\text { for content, and major role } \\
\text { in the acquisition of data }\end{array}$ \\
\hline $\begin{array}{l}\text { Anna-Elina } \\
\text { Lehesjoki, PhD }\end{array}$ & $\begin{array}{l}\text { Folkhälsan Research } \\
\text { Center, Helsinki, Finland; } \\
\text { Department of Medical and } \\
\text { Clinical Genetics, Medicum, } \\
\text { University of Helsinki, } \\
\text { Finland }\end{array}$ & $\begin{array}{l}\text { Drafting/revision of the } \\
\text { manuscript for content, } \\
\text { including medical writing } \\
\text { for content, and major role } \\
\text { in the acquisition of data }\end{array}$ \\
\hline $\begin{array}{l}\text { Karen L. } \\
\text { Oliver, PhD }\end{array}$ & $\begin{array}{l}\text { Population Health and } \\
\text { Immunity Division, The } \\
\text { Walter and Eliza Hall } \\
\text { Institute of Medical } \\
\text { Research, Parkville; } \\
\text { Department of Medical } \\
\text { Biology, The University of } \\
\text { Melbourne, Australia; } \\
\text { Epilepsy Research Centre, } \\
\text { Department of Medicine, } \\
\text { University of Melbourne, } \\
\text { Austin Health, Heidelberg, } \\
\text { Victoria, Australia }\end{array}$ & $\begin{array}{l}\text { Drafting/revision of the } \\
\text { manuscript for content, } \\
\text { including medical writing } \\
\text { for content, major role in } \\
\text { the acquisition of data, and } \\
\text { analysis or interpretation of } \\
\text { data }\end{array}$ \\
\hline $\begin{array}{l}\text { Samuel F. } \\
\text { Berkovic, MD }\end{array}$ & $\begin{array}{l}\text { Epilepsy Research Centre, } \\
\text { Department of Medicine, } \\
\text { University of Melbourne, } \\
\text { Austin Health, Heidelberg, } \\
\text { Victoria, Australia }\end{array}$ & $\begin{array}{l}\text { Drafting/revision of the } \\
\text { manuscript for content, } \\
\text { including medical writing } \\
\text { for content, major role in } \\
\text { the acquisition of data, } \\
\text { study concept or design, } \\
\text { and analysis or } \\
\text { interpretation of data }\end{array}$ \\
\hline
\end{tabular}

\section{References}

1. Franceschetti S, Michelucci R, Canafoglia L, et al. Progressive myoclonic epilepsies: definitive and still undetermined causes. Neurology. 2014;82(5):405-411.

2. Vanni N, Fruscione F, Ferlazzo E, et al. Impairment of ceramide synthesis causes a novel progressive myoclonus epilepsy. Ann Neurol. 2014;76(2):206-212.

3. Muona M, Berkovic SF, Dibbens LM, et al. A recurrent de novo mutation in KCNC1 causes progressive myoclonus epilepsy. Nat Genet. 2015;47(1):39-46.

4. Oliver KL, Franceschetti S, Milligan CJ, et al. Myoclonus epilepsy and ataxia due to KCNC1 mutation: analysis of 20 cases and K+ channel properties. Ann Neurol. 2017; 81(5):677-689.

5. Courage C, Oliver KL, Park EJ, et al. Progressive myoclonus epilepsies-Residual unsolved cases have marked genetic heterogeneity including dolichol-dependent protein glycosylation pathway genes. Am J Hum Genet. 2021;108(4):722-738.

6. Canafoglia L, Robbiano A, Pareyson D, et al. Expanding sialidosis spectrum by genome-wide screening: NEU1 mutations in adult-onset myoclonus. Neurology. 2014;82(22):2003-2006.

7. Trinh J, Imhoff S, Dulovic-Mahlow M, et al. Novel NAXE variants as a cause for neurometabolic disorder: implications for treatment. J Neurol. 2020;267(3): 770-782.

8. Berkovic SF, Carpenter S, Evans A, et al. Myoclonus epilepsy and ragged-red fibers (MERRF) 1. A clinical, pathological, biochemical, magnetic resonance spectroscopic and positron emission tomographic study. Brain. 1989;112(pt 5) 1231-1260.

9. Michelucci R, Serratosa JM, Delgado-Escueta AV, et al. Progressive myoclonic epilepsies. In: Bureau M, Genton P, Dravet C, et al (eds) Epileptic Syndromes in Infancy, Childhood and Adolescence. (6th ed): John Libbey Eurotext. 2019: 571-610.

10. Satishchandra P, Sinha S. Progressive myoclonic epilepsy. Neurol India. 2010;58(4): 514-522. 


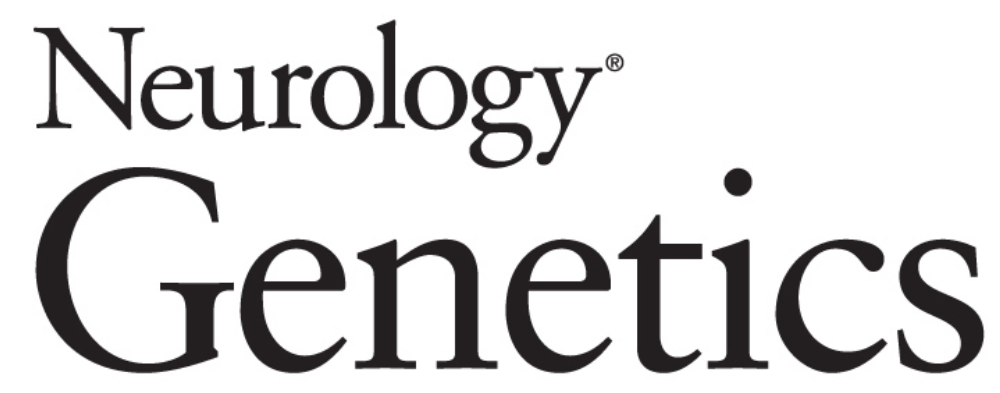

Progressive Myoclonus Epilepsies: Diagnostic Yield With Next-Generation Sequencing in Previously Unsolved Cases

Laura Canafoglia, Silvana Franceschetti, Antonio Gambardella, et al. Neurol Genet 2021;7;

DOI 10.1212/NXG.0000000000000641

This information is current as of November 12, 2021

Neurol Genet is an official journal of the American Academy of Neurology. Published since April 2015, it is an open-access, online-only, continuous publication journal. Copyright Copyright ( 2021 The Author(s).

Published by Wolters Kluwer Health, Inc. on behalf of the American Academy of Neurology.. All rights reserved. Online ISSN: 2376-7839.

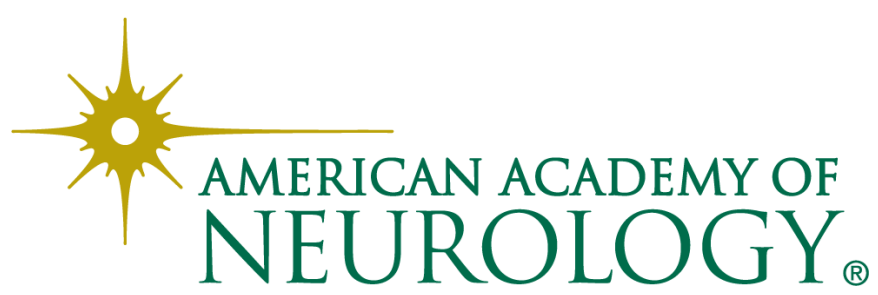




\section{Updated Information \& Services}

References

Citations

Subspecialty Collections

Permissions \& Licensing

Reprints including high resolution figures, can be found at:

http://ng.neurology.org/content/7/6/e641.full.html

This article cites 9 articles, 0 of which you can access for free at: http://ng.neurology.org/content/7/6/e641.full.html\#\#ref-list-1

This article has been cited by 2 HighWire-hosted articles:

http://ng.neurology.org/content/7/6/e641.full.html\#\#otherarticles

This article, along with others on similar topics, appears in the following collection(s):

\section{All Genetics}

http://ng.neurology.org//cgi/collection/all_genetics

Generalized seizures

http://ng.neurology.org//cgi/collection/generalized_seizures

Myoclonus

http://ng.neurology.org//cgi/collection/myoclonus

Myoclonus; see Movement Disorders/myoclonus

http://ng.neurology.org//cgi/collection/myoclonus_see_movement_diso rders-myoclonus

Information about reproducing this article in parts (figures,tables) or in its entirety can be found online at:

http://ng.neurology.org/misc/about.xhtml\#permissions

Information about ordering reprints can be found online:

http://ng.neurology.org/misc/addir.xhtml\#reprintsus

Neurol Genet is an official journal of the American Academy of Neurology. Published since April 2015, it is an open-access, online-only, continuous publication journal. Copyright Copyright $\odot 2021$ The Author(s). Published by Wolters Kluwer Health, Inc. on behalf of the American Academy of Neurology.. All rights reserved. Online ISSN: 2376-7839.

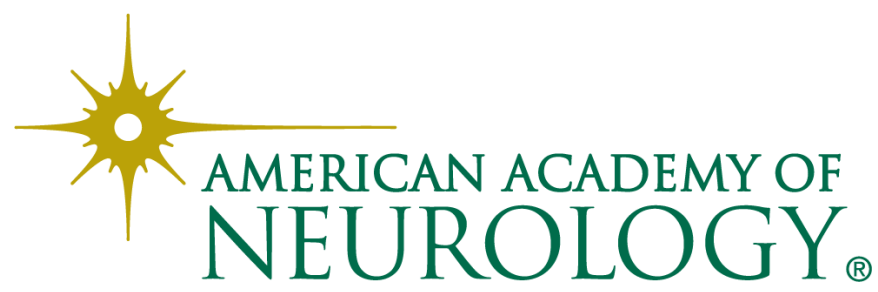

